\title{
The Role of Buying Motivation in Moderating Online Shopping Behaviour
}

\author{
Junita Safitri \\ Doctoral Student of Universitas Sumatera Utara \\ Management Departement \\ Faculty of Business \& Economics \\ Medan, Indonesia \\ junitasafitri@gmail.com \\ Paham Ginting \\ Universitas Sumatera Utara \\ Management Departement \\ Faculty of Business \& Economics \\ Medan, Indonesia
}

\author{
Endang Sulistya Rini \\ Universitas Sumatera Utara \\ Management Departement \\ Faculty of Business \& Economics \\ Medan, Indonesia \\ Arlina Nurbaity Lubis \\ Universitas Sumatera Utara \\ Management Departement \\ Faculty of Business \& Economics \\ Medan, Indonesia \\ junitasafitri@gmail.com
}

\begin{abstract}
Nowadays Online Shopping have been part of our life. It has been known since internet was introduced to Indonesia. Every day millions of people are going online, but just some of them going online for shopping. In fact, online shopping hasn't been the main option when customer still bought offline especially for College student in Aceh Province. Online shopping behavior are influenced by many factors. These research examine the role of buying motivation in moderating online shopping intention. Purpose of this study is to identify the role of motivation as a moderating variable in measuring the relationship among the Influencing Factors and online buying intention. The subject of study is university student who experiences online shopping. This study was conducted using 164 respondents as sample which were taken from several universities in Aceh Province. Observation and Questionnaires were using as data collecting method while Partial Least Square (PLS) using as data analyzing method. This study resulted that Buying intention significant in influencing actual buying. Perceived Usefulness significant in influencing buying intention.
\end{abstract} Buying

Keyword: Buying Motivation, Buying Intention, Actual

\section{INTRODUCTION}

Market is a place where seller and buyer meet. We can easily show the place and name the address. Today the place we know as market place is still there with all its story. Some shopper still visits it for classic reason shopping. But market place today have been shifted by Market space. Don't ask the address because you cannot find it. The improvement of technology has changed numerous things in our life. The market is just one of example. Who needs to leave their desk for shopping when the internet brings you the stores. It offers you hundred stores that can be visited easily just with one click away. They offer you product, how to consume it, name you the price. It even provides the testimonies of early shoppers and thirty days guarantee to exchange the product if it's under your expectation. It occurs worldwide, and everyone welcomes to enjoy this changes.

It also occurs in Indonesia. It was in 1997 when internet was introduced for the first time in Indonesia. It was and still changing so many things that we do in live; the way children study, how we spend our time, how we purchase even change our way of connecting others. In Indonesia 62 percent netizen going online for shopping. Aceh is one of the provinces that located in Indonesia. For the past two years, the Acehnese experienced the decline in internet usage. This statement based on the result of one of the national survey in Indonesia [1].

Technology Acceptance Model (TAM) was introduced by Davis [9]. TAM was an adaptation of Theory of Reason Action that was studied by Fishbein and Azjen [11]. This model proposes that an individual actual behavior is determined by the person's intention to perform the behavior where this intention is influenced jointly by the individual's attitude and subjective norms. The Classic TAM aimed to measure the user intention to adopt technology. TAM used two beliefs toward intention of technology usage. According to Davis [9] perceived ease of use and perceived usefulness was believed in determining user intention toward technology usage.

Everyone always needs reason to do anything. Shopping is one of activity that must be done when we need to buy something we cannot provide. The motivation of buying online measure in two dimensions; utilitarian and hedonism dimensions [14]. Buying motivation will become a reason why people shop. These two dimensions different one another, utilitarian believes that buying the right product in an efficient and timely manner while hedonism defines buying or shopping as a way to find happiness, pleasure, experience and positive vibes at the same time. This research aim to evaluate the factors that influence online shopping in Aceh Province. 
This research also involve the role of buying motivation as moderating variable to influence the relationship between perceived ease of use and online buying intention and also to influence the relation between perceived usefulness and online buying intention.

\section{LITERATURE REVIEW}

\section{A. Perceived Ease of Use}

Perceived ease of use is part of classical Technology Acceptance Model (TAM) which was built by Davis [9]. The origins of TAM can be traced back to the Theory of Reasoned Action (TRA) The term is defined as the individual's perception that using the new technology will be free of effort [9]. According to David [9], Perceived ease of use is one of determinant of technology usage intention. In this research context ease of use refers to how easy online shopping using an internet as a medium.

\section{B. Perceived Usefulness}

Perceived usefulness defined as the individual's perception that using the new technology will enhance or improve her/his performance [9]. In our research context, the usefulness refers to the benefit of internet as online shopping medium.

\section{1) Online Buying Intention}

Online shopping is an exchange process between buyer and seller without intermediary services using the internet as a medium. In this research context, online buying intention refers to early stages of decision making; recognition, awareness, alternatives, and evaluation. They shopping activities can be done in online stores (online websites) or social media that provides seller but usually only individual seller without regulation that guarantee shopper from fraud issue.

\section{2) Buying Motivation}

The motivation for shopping measures using two dimensions. It includes both utilitarian and hedonic dimensions. Some internet shoppers found shopping as a solution for their constraint while some enjoyed shopping as fun, pleasure, experience and enjoyment [14]. The Utilitarian shopper found online shopping as solution to shop the right product without wasting time. While in contrast Hedonism shopper found shopping for fun, exploring, playing and seeking new experience from website. In this research context buying motivation act as moderating variable for measuring relation of two perceptions in influencing online shopping intention.

\section{3) Actual Buying}

Actual Buying defines as a real action that is formed by intention and purchasing power. Actual buying is the latest stage of decision-making process. Actual buying means paid and brought the product from the seller not just intended to buy. Numerous research state that intention is the best construct to predict the actual buying [9].

\section{RESEARCH METHODOLOGY}

\section{A. Research Hypothesis}

Perceived ease of use is one of construct that believed influence behavioral intention to use technology [9]. Ramayah and Ignatius [20] hypothesized the relation between perceived ease of use and online shopping intention.

H1: Perceived Ease of use influence online buying intention

Along with Perceived ease of use Davis [9] measured classical Technology Acceptance Model using two constructs Perceived ease of use and perceived usefulness. Perceived usefulness and online shopping intention hypothesized in a study about purchasing a particular brand [8]. Ramayah \& Ignatius [20] also hypothesized perceived usefulness influenced online shopping intention.

H2: Perceived Usefulness influence online buying intention

Online buying intention is the best predictor to measure online actual buying [5],[4],[15]. Actual usage of technology influenced by intention to use the system [9]. David studied the technology usage but this classic model can be used to measure the activity

\section{H3: Online Buying Intention influence Actual Buying}

Buying motivation always interesting to discuss. Buying motivation measure in utilitarian and hedonism dimensions. In some research these two dimensions used in different name to measure buying intention. In this research context buying motivation used as moderating variable to influence the relation of two beliefs perceived ease of use; perceived usefulness and online buying intention.

A utilitarian has precise purpose shopping behavior. They purchased based on rational needs that tied to a particular purpose. [19]. The most important thing about shopping for utilitarian is buying efficiently and how to accomplish its purpose with the least cost. Shopping is a focus for finding and buying a product at the best price for utilitarian. Delafrooz et al.[10] also found that utilitarian orientation aspect influence shopper's attitude to purchase online. Hedonist is an experiential shopper. Besides gathering shopping information hedonist also finds shopping for fun, adventure and fantasy [17]. For Hedonist shopping experience is more important than the common shopping reason. Even in his research Childers et al. [6] stated that interactive level that offered by website was become a supporting factor for hedonist to enjoy online shopping better than ordinary online environment.

H4: Buying Motivation Influence Buying Intention

H5: Buying motivation as moderating variable in influencing relation between perceived ease of use and online buying intention

H6: Buying motivation as moderating variable in influencing relation between perceived ease of use and online buying intention 


\section{B. Research Approach}

\section{1) Research Design}

Survey research was the predominant methodology used in this study. The purpose of the research is to measure the affecting factors of actual buying and online buying intention. The measurement device adopted from Classical Technology Acceptance Model (TAM) [9]. The structural Model modified by adding construct actual buying and buying motivation as a moderating variable.

\section{2) Sample}

Sample of this research is college student who experiences online shopping. The sample is collected from a few local universities that locate in Aceh Province. The descriptive statistic will be used as data collection method. While the data will be analyzed by using Partial Least Square (PLS).

\section{RESEARCH FINDING}

\section{A. Data Overview}

A total of 200 questionnaires were distributed to the respondents. From total 200 questionnaires, only 164 returned on time for the analysis process. The 164 respondents consisted of 107 female and 57 male, age between 18 to 21 years old. The respondents stated that 60.4 percent bought clothes from internet while Instagram was the most often used media for online shopping. 40,9 percent confirmed using instagram for online shopping, and 21.3 percent confirmed using Lazada as a website option for online shopping.

\section{1) Validity and Reliability Test}

Table 4.1 Reliability Test

\begin{tabular}{|l|c|c|}
\hline \multicolumn{1}{|c|}{ Construct } & $\begin{array}{l}\text { Average Varian } \\
\text { Extracted }\end{array}$ & $\begin{array}{l}\text { Composite } \\
\text { Reliability }\end{array}$ \\
\hline $\begin{array}{l}\text { Perceived Ease of } \\
\text { Use }\end{array}$ & 0.664 & 0.887 \\
\hline $\begin{array}{l}\text { Perceived } \\
\text { Usefulness }\end{array}$ & 0.587 & 0.850 \\
\hline $\begin{array}{l}\text { Online Buying } \\
\text { Intention }\end{array}$ & 0.690 & 0.816 \\
\hline $\begin{array}{l}\text { Buying } \\
\text { Motivation }\end{array}$ & 0.687 & 0.922 \\
\hline Actual buying & & 0.814 \\
\hline
\end{tabular}

The reliability test was examined based on the value of Average Variance Extracted (AVE) must be above 0.50 [12] while for composite reliability (CR) the value must be above 0.60 [3]. Based on the Tabel 1 we can conclude that . Perceived ease of use with AVE value 0.664 and $C R$ value 0.887 was reliable. Perceived Usefulness with AVE Value 0.587 and CR Value 0.850 was reliable. Online buying intention with AVE Value 0.690 and CR Value 0.816 was reliable. Buying Motivation with AVE Value 0.687 and CR Value 0.814 was reliable. Actual Buying with AVE Value 0.747 and CR Value 0.922 was reliable.

\section{2) PLS Analysis}

Partial Least Square analysis were conducted to determine the relationship between dependent latent variable online buying intention and independent latent variable perceived ease of use and perceived usefulness. It was also accommodated to test the role of buying motivation as moderating variable to measure the relationship between perceived ease of use and online buying intention, and the relationship between perceived usefulness and online buying intention. Lastly, it tested the relationship between online buying intention and actual online buying

\section{3) Hypothesis Testing}

\begin{tabular}{|l|c|l|c||}
\hline \multicolumn{1}{|c|}{ Table 4.2 Hypothesis Testing } \\
\hline $\begin{array}{l}\text { Variable } \\
\text { relationship }\end{array}$ & $\begin{array}{l}\text { Path } \\
\text { Analysis } \\
\text { Coefficient }\end{array}$ & P- Value & Result \\
\hline $\begin{array}{l}\text { Perceived Ease } \\
\text { of Use - } \\
\text { Buying } \\
\text { Intention }\end{array}$ & 0.085 & 0.162 & Insignificant \\
\hline $\begin{array}{l}\text { Perceived } \\
\text { Usefulness- } \\
\text { Buying } \\
\text { Intention }\end{array}$ & 0.150 & 0.017 & Significant \\
\hline $\begin{array}{l}\text { Buying } \\
\text { Motivation- } \\
\text { Buying } \\
\text { Intention }\end{array}$ & 0.186 & 0.010 & Significant \\
\hline $\begin{array}{l}\text { Buying } \\
\text { Intention- } \\
\text { Actual Buying }\end{array}$ & 0.749 & 0.000 & Significant \\
\hline $\begin{array}{l}\text { Buying } \\
\text { Motivation } \\
\text { moderating } \\
\text { Perceived Ease } \\
\text { of Use } \\
\text { Buying } \\
\text { Intention }\end{array}$ & -0.182 & 0.002 & Insignificant \\
\hline $\begin{array}{l}\text { Buying } \\
\text { Motivation } \\
\text { moderating } \\
\text { Perceived } \\
\text { Usefulness- } \\
\text { Buying } \\
\text { Intention }\end{array}$ & & & \\
\hline & & & \\
\hline & & & \\
& & & \\
\hline
\end{tabular}

\section{4) Result}

All result will be interpreted based on Chin [7].

H1: Perceived Ease of use influence online buying intention perceived ease of use found insignificant in influencing buying intention. Path Analysis coefficient shown value 0.085 with 0.162 on P-Value. The PLS Result explained that perceived ease of use insignificant in influencing online buying intention.

In this research context, online Buying Intention was not shaped by perceived ease of use. Some previous research 
stated that perceived is of use was one of construct that determined. Buying intention [9].The interpretation would be that perceived ease of use was not considered when shopper wanted to purchase online. There was a study support this finding. Harn et al.[13] found that perceived ease of use had no significant influence on group purchase intention. Although the research was done to measure grup's purchase intention but considering grup's purchase decision originated from individual's decision. In this context research perceived ease of use was not one of the factor that influences college student in Aceh Province.

TAM was studied for the first time in 1989 by Davis [9]. TAM was the breakthrough for measuring technology usage, but as the time goes by the influence of perceived ease of use as part of determinants beliefs that influence buying intention keep declining.

H2: Perceived Usefulness influence online buying intention.

Perceived Usefulness is positively significant in influencing online buying intention. Path analysis coefficient 0.150 and $p$-Value 0.017 explained that as much as 15 percent of online buying intention shaped by perceived usefulness. Usefulness is one of the reasons why customer purchase online. Cho [8] found that perceived usefulness had a statistically significant effect on online buying intention. Lim et al.[22] also found that perceived usefulness influenced online buying intention. In this research context, we may conclude that college student in Aceh Province started realizing that online buying behavior gave them numerous benefits. Even though they have not optimized the online shopping intention yet since they still purchase frequently at Social Media e.g., Instagram, but 21 percent of them have tried buying at Lazada. The amount of respondent that did the purchase at Lazada start showing the good sign that the college student of Aceh Province start using world wide web (WWW) for online shopping option. As the time passes they will realize which one brings more benefits as an option for online shopping; Social Media or World Web Wide that provided official online store.

H3: Online Buying Intention influence Actual Buying Online buying intention positively significant influenced actual buying. Path Analysis coefficient 0.749 with P-Value 0.000 explained that online buying intention positively significant influenced actual buying. 74.9 percent of actual buying was shaped by online buying intention. Al-Jabari et al.[16] found significant relationship between online buying intention and actual buying. Though using different model to measure the constructs but the result contributed the same conclusion. Lim et al.[21] also found that online buying intention influence actual online buying. In this research context, we interpreted that actual online buying one of college student in Aceh Province was shaped by online buying intention

H4: Buying Motivation influenced Online buying intention. Statistically, Path analysis coefficient 0.186 while PValue 0.010 shown that buying motivation significant in influencing online buying intention. The coefficient can be interpreted as 18.6 percent of online buying intention of college student of Aceh Province was explained by buying motivation.
H5: Buying motivation as moderating variable in influencing relation between perceived ease of use and online buying intention.

Buying motivation found insignificant in moderating the relationship between perceived ease of use and online buying intention. Statistically path coefficient analysis -0.182 and PValue 0.002 shown that buying motivation significant as moderating variable in relationship of perceived ease of use and online buying intention. Referring to Baron and Kenny [2] who stated that if the main effect( the relationship between perceived ease of use and online buying intention) found insignificant, the other effect as moderating or mediating measurement cannot be added. Even though in the analysis data (Partial Least Square -PLS) it was possible to do, since the measurement examined simultaneously. Based on this reality we could interpret that though it was statistically significant but because of the relationship between perceived ease of use and online buying intention found to be insignificant, the measurement had to be canceled.

H6: Buying motivation as moderating variable in influencing relation between perceived usefulness and online buying intention.

Buying Motivation found insignificant in moderating relationship between perceived usefulness and online buying intention. Statistically, path analysis coefficient 0.035 while pvalue 0.0599 shown that the $\mathrm{P}-$ Value above the number required. This condition explained that college student in Aceh Province did not need any motivation for online buying intention. Their involvement in online shopping activity was because usefulness of the activity. Both dimensions have not weakened or strengthened the relationship between perceived usefulness and online buying intention.

\section{CONCLUSION}

Technology Usage is part of our life. The Classic Technology Acceptance Model (TAM) had been adopted for years to measure this worldwide phenomenon. The Classic TAM also use in this research. The three original constructs were extended by adding two other constructs that related to the importance of the research. Perceived ease of Use, Perceived usefulness and Online Buying Intention were found on classic TAM, while Actual buying and Buying Motivation as an additional variable on TAM extended version. The result of the research shown that online buying intention was shaped by perceived usefulness and buying motivation. While actual buying formed by online buying intention. Perceived ease of use found insignificant in influencing online buying intention. It was hard to state or conformed easiness when we did not use the technology offered. A college student in Aceh Province have not optimized the usage of internet for online shopping Technology could be said useful only after using it. Most of them were rather purchasing at Social Media than the official online store (WWW). The amount of shopper who actually purchases online can be found more at Social Media than at official online store. The influencing factor that drove online buying intention in this research were perceived usefulness and buying motivation.

In this research, buying motivation had higher influence than perceived usefulness. The interpretation would be the number the college student in Aceh Province who purchased 
online because of buying motivation was higher than perceived usefulness. It explained that for college student in Aceh being utilitarian or hedonist influenced online buying intention. Purchasing for fun or necessity significantly influenced online buying intention. Based on the result we can conclude that Aceh's college student must know more about the usefulness of online buying so they can optimize the usage of internet for online shopping. Buying motivation triggered online shopping intention for most of the college student in Aceh Province. Buying intention found insignificant as moderating variable in this research.

\section{REFERENCE}

[1] APJII.2016.Profil Pengguna Internet Indonesia (Edisi Pertama) Jakarta APJII (APJII:2016)

[2] Baron, M Reuben and David A. Kenny.The Moderator-Mediator variable distinction in Social Psychological Research: Conceptual, Strategic and Statistical Considerations. Journal of Personality and Social Psychology Vol.51, No.6,1173-1182,1986

[3] C.E.Werts,R.L.Linn and K.G.Joreskog. Intraclass Reliability Estimates: Testing Structural Assumptions. Journal of Educational and Psychological Measurement 34(1),25-33,1974

[4] Celik, Eray H \& Veysel Yilmaz.Extending The Technology Acceptance Model for Adoption of E-Shopping by consumers in Turkey. Journal of Electronic Commerce Research Vol.12 No.2011

[5] Chen L, Gillenson M.L,\& Sherrel D.L.Enticing online consumers: an Extended Technology Acceptance perspective. Information and Management, 39(8).705-719,2002

[6] Childers TL,Car CC,Peck J,Carson S. Hedonic and Utilitarian Motivations For Online Retail Shopping Behavior. J.Retailing 77: 511535,2001

[7] Chin,W.W.The Partial Least Squares approach for Structural Equation Modelling in GA Marcoulides (Ed), Modern Methods for Business Research (pp.295-236). London: Erlbaum Associates, 1998

[8] Cho, C Yoon. Exploring Factors that affect Usefulness,Ease of Use, Trust and Purchase intention in the online environment. International Journal of Management and Information systems. 2015

[9] Davis, F.D.Perceived Usefulness, Perceived Ease of Use and User Acceptance of Information Technology. MIS Quarterly, 13(3), 319 339, 1989

[10] Delafrooz, Narges. Laily H.Pain \& Sharifah Azizah Haron.Factors Affecting Students' Attitude toward online shopping. African Journal Of Business Management Vol.3(5) pp.200-209,2009

[11] Fishbein $M$ and Azjen I.Belief,Attitude,Intention and Behavior: An Introduction to Theory and Research, Addison Wesley Reading, MA, 1975

[12] Fornell C andLarcker,D.F. Evaluating Structural Equation Models with unobservable variables and measurement error.Journal of Marketing Research 18 (1) pp.39-50,1981

[13] Harn Tracie Chin Sook, Geoffrey Harvey Tanakinjal,Stephen Liason Sondoh Jr and Hamid Rizal. Determinants of online group buying behavior: The Moderating Role of Informational Social Sciences Jurnal Pengurusan 41 (2014) 133-143,2014

[14] Hirshman C.Elizabeth \& Morris B. Holbrook. Hedonic Consumption: Emerging concepts, Methods and Propositions.Journal Of Marketing Vol.46 No.3 1982 pp.92-101,1982

[15] Klopping I and Mckinney E. Extending The Technology Acceptance Model and the Task-Technology fit Model to Consumer E-Commerce. Information Technology, Learning and Performance Journal 22 (1), 3548,2004

[16] Mohammed A Al-Jabari, Siti Norezam Othman and Nik Kamariah Nik Mat. Actual online shopping behavior among Jordanian Customers. American Journal of Economics June 2012, Special Issue: 125-129,2012
[17] Monsuwe, Y Tonita Perea, Benedict GC Dellaert \& Ko De Ruyter. What drive consumers to shop online? A Literature Review. International Journal of Service Industry Management 15 (1):102-121. February 2004

[18] Moon J. W \& Kim Y.G .Extending the Technology Acceptance Model (TAM) for a World-Wide-Web context. Information and Management, 38 (4), 217-230,2001

[19] Sangmoon Kim and Eui Hang Shin.2002.A Longitudinal Analysis of Globalization and Regionalization in International Trade: A Social Network Approach. Social Forces December 2002

[20] Ramayah,T dan Ignatius J.Impact of Perceived Usefulness, Perceived Ease of Use dan Perceived Enjoyment on intention to shop online.ICFAI Journal of Systems Management (IJSM) Vol.III No.3 pp.36-51,2005

[21] Yi jin Lim, Abdullah Osman, Shahrul Nizam Salahuddin, Abdul Rahim Romle and Safrizal Abdullah.Factors Influencing online shopping behavior: The Mediating Role of Purchase Intention Procedia Economics and Finance Vol.35, 2016, Pages 401-410,2016

[22] Yi Jin,Lim, Abdullah Bin Osman,Mohd Suberi Bin AB Halim. Perceived Usefulness and trust towards consumer Behaviors: A Perspective of Consumer online shopping. Journal of Asian Scientific Research 2014,4 (10): 541-546 